\title{
The Investigation and Image of Foreign Exhibitions in Zhoushan Pilot Free Trade Zone
}

\author{
Cui Yufan, He Fangjie* \\ Zhejiang Ocean University, Zhejiang, China
}

*Corresponding Author: He Fangjie, Zhejiang Ocean University, Zhejiang, China

\begin{abstract}
Foreign exhibition plays an important role in the process of foreign exchange and it is also a key indicators in reveling the development status of the city. The article will propose suggestions by investigating current situation of foreign exhibition in Zhoushan Pilot Free Trade Zone and analyze strengths, weakness, opportunities and threats of developing exhibition industry in Zhoushan Pilot Free Trade Zone. The article will also put forward ideas on planning new foreign exhibitions.
\end{abstract}

Keywords: exhibition industry, Zhoushan, investigation

\section{INTRODUCTION}

Zhoushan is a prefecture-level city which locates in the northeast of Zhejiang Province, China. Zhoushan has many excellent features, including long history of marine culture and good geographical environment. On 8 July 2011, the central government approved Zhoushan as Zhoushan Archipelago New Area, a state-level new area. On April 1, 2017, Zhejiang province announced the launch of the China (Zhejiang) Pilot Pilot Free Trade Zone. Zhoushan Pilot Free Trade Zone is a 119.95-square-kilometer zone, made up of both inland and anchorage areas, is a key part of the country's Belt and Road Initiative and the Yangtze River Economic Belt.

Exhibition is a publicity campaign to exhibit products and technology, develop business channel, sales promotion and spread brand. There are many kinds of exhibitions, including trade exhibition, consumer exhibition, comprehensive exhibition, professional exhibition and so on. Exhibition industry is the center and supporting point of exhibition economy. The development of exhibition can propel developments in few related industries. The flourish of exhibition industry can accelerate the harmonious development of urban traditional industry, high-tech industry and modern technology industry. By doing so, it will increase employment opportunities. Good exhibitions will bring a lot of benefits to the development of enterprise and related city. And whether a city can hold large-scale exhibitions successfully is also a test of urban development.

China is a nation with great sea power, and the government has been always attach importance to the development of Marine economy. Zhejiang Zhoushan Pilot Free Trade Zone is the only region that focus on Marine economy. In 2017, Zhoushan has reached the growth of the output value of the Marine economy for 82.4 billion yuan, which increases the year-on-year growth by $5 \%$ and accounts $67.6 \%$ of GDP, and became one of the cities with the highest proportion of Marine economy. According to the government documents, the growth of GDP in the first three quarters of 2018 have reached 7.2 percent. In March,2017, the released of <China(Zhejiang) Pilot Free Trade Zone Overall Plan> had mentioned to promote Pilot Free Trade and expand new forms of trade and investment. These years, Zhoushan Pilot Free Trade Zone have host few well -known foreign exhibitions. With the influence of Pilot Free Trade bonus, the development of Zhoushan Pilot Free Trade Zone will get improved.

\section{Current Exhibitions in Zhoushan City}

Zhoushan has beautiful scenery, the air quality is the top 5 in China and has unique Buddhist culture and marine culture. Industrial advantage is one of the basic conditions that develop exhibition industry in small and medium-sized cities. Due to characteristic folk culture and island resources advantages, right now Zhoushan Pilot Free Trade Zone has many exhibitions that has distinct Marine culture 
features, including China Putuo Mountain Guanyin Cultural Festival, China Zhoushan International Sand Sculpture Festival, China Buddha Tea Culture Festival and China Zhoushan Seafood Festival. China Zhoushan International Sand Sculpture Festival opened the door to sand sculpture art and sand sculpture tourism. It also created a precedent of China traditional tourism. But China Zhoushan International Sand Sculpture Festival has little influence in China, number of people at show are very small. It also don't have too much related news reports and it is difficult to appeal people to attend the exhibition. China Putuo Mountain Guanyin Cultural Festival has been held for over 15 years. But the target audience is small and has many restrictions. It is also difficult to draw extensive attention.

Except those exhibitions, the most important foreign exhibitions are International Islands Tourism Expo, referred to as 'IITEZS'. Since 2015, every year IITEZS has promoted the construction of international island tourism and leisure destination. In 2018, IITEZS attracted over 230 domestic and overseas exhibitors and 3, 3000 visitors. The spot trade in IITEZS had reached about 43 million yuan, online and offline transaction volume had reached 142 million yuan. IITEZS increased the relationship and diplomacy between island country and coastal city, not only share advance experience of island tourism, but also expand the voice of islands.

\section{Problems of Current Exhibitions in Zhoushan City}

Take IITEZS as example. Based on interview of volunteers in IITEZS, over $85 \%$ volunteers mentioned that they had attended only few exhibitions, some of them never attended any exhibitions in Zhoushan . About $70 \%$ of volunteers stated that they are not satisfied with the current situation of foreign exhibitions in Zhoushan. And volunteers listed the following problems.

\subsection{Lack of Management}

Over $67 \%$ of volunteers mentioned the government pays a little attention to the IITEZS and lack of publicity which lead to the situation that at the end of the exhibition, there are more exhibitors and staffs including volunteers than visitors and many exhibitors chose to leave the fair before the end of the exhibition. The training and arrangement of volunteers are unreasonable, exhibitors and

\subsection{Unreasonable Location and Arrangement}

IITEZS has its own permanent site in Zhoushan, but 2018 IITEZS was held in Putuo National Fitness Center. The arrangement of space is unreasonable, most of the space was arranged to domestic stages, island stages has too small a space to show express distinctive culture. About $70 \%$ of domestic stages became the bazaar instead of expressing island culture.

\subsection{Misarrangement of Time}

The time of IITEZS and International Petroleum and Natural Gas Enterprises Conference (Reffed to as 'IPEC') was very close. The government focus more time on IPEC and neglected the publicity of IITEZS.

Since the implementation of the open policy, Marine economy in Zhoushan has developed rapidly and Zhoushan is developing to better city that has a variety of industries and relatively complete Marine economic system. Zhoushan has distinctive marine features and deserve to be made most use of them.

\section{SWOT ANALYZES OF EXHIBITION INDUSTRY DEVELOPMENT IN ZHOUSHAN}

\subsection{Strength}

\subsubsection{Abundant Tourism and Culture Resources}

Abundant tourism and marine culture resources are important features for Zhoushan to develop exhibition industry. Zhoushan is called 'city with thousands of islands', not only it is close to Ningbo, Shanghai, Hangzhou and other medium and large scale cities, but also has strong geographical advantages. Zhoushan has good air quality, beautiful scenery, unique marine culture and characteristic Buddhist culture. In 2018, the total number of tourist reception has up to 63.21 million passengers which has increased $14.79 \%$ compared with 2017, revenues was over 94.2 billion which has increased 16.8\% compared with 2017. Moreover, as important tourism city, Zhoushan also has favourable infrastructure and starred hotel. 


\subsubsection{Good Geographical Conditions}

Zhoushan locates in intersection of east China's coastline and the Yangtze river's waterway. Zhoushan is also very close to the broad economic hinterland of the Yangtze river delta. Ningbo-Zhoushan Port is now developing 'oceanic economy' and the cross-sea bridge has connect Zhoushan and other large cities. In the future, Zhoushan will become a traffic hub city which has multiple transportation systems.

\subsection{Weakness}

\subsubsection{The Exhibition Quality is Low}

First, Zhoushan lacks of influential personalized characteristic exhibition brand. A successful professional exhibition mush have the following features: Gather the most representative enterprises and its products in an industry or field, and can organize plenty of professional buyers. Right now, Zhoushan has held many exhibitions, but those exhibitions all don't have high reputation and can't hold mature and famous at home and abroad exhibitions such as China Import and Export Fair, East China Import and Export Fair, China Yiwu international Commodities Fair and so on. Second, the scale of exhibition activities is small. Exhibitions are economies of scale, when exhibitions have reached a considerable scale, can they have competitiveness to against risk and thus survive and develop to get a foothold in the exhibition industry. Based on domestic experience from exhibition industry, the exhibition area should greater than 30,000 square meters so that exhibition can get profit. Due to small amount of economy in Zhoushan and limited market volume, some professional exhibition seems to be inferior when comparing with exhibitions in other cities. For example, compared with Xiamen, the development of yacht fair in Zhoushan is not so good and competitive.

\subsubsection{Lack of Professional}

Exhibition industry required highly professional skills and talents. It involves many aspects including plan, marketing, management and other realms. An important reason for slow development of exhibition industry in Zhoushan is that it dearth strategic goals and plan for industry development. Right now most of exhibitions in Zhoushan Pilot Free Trade Zone are held by local government, although it can bring temporary effect; in the long run, the method limited the development of market and didn't active market elements.

Professionals are an important determinant to develop exhibitions. Exhibition talents in Zhoushan Pilot Free Trade Zone, including talents in exhibition marketing, planning, service and other fields are still have greater demand than supply. The lack of professionals has caused conspicuous limitation to further development in exhibition industry in Zhoushan. At the same time, the exhibition professional training, use, management and introduction systems are left behind seriously. Moreover, these drawbacks make Zhoushan difficult to propel the development of foreign exhibitions.

Due to the lack of related talents, those people who are assigned to hold the exhibition don't have professional skills and the planning of exhibition is not so good as expected. Thus it leads to the consequence that the quality of exhibition is below to the average and can't cause extensive attention and build up good reputation. At present, large scale exhibitions held in Zhoushan usually hire exhibition company outside the city. For example, in 2007, the planning service of The First China Zhoushan International Ocean Exposition was provided by Hangzhou Jiade exhibition services co. LTD. In 2018, the planning service of International Islands Tourism Expo was provided by Ctrip, China's biggest web travel firm. Moreover, the planning service of 2018 China (Zhejiang)Pilot Pilot Free Trade Zone International Maritime Exhibition was provided by Beijing Zhenwei Exhibition co. LTD. Those examples shows that in Zhoushan, there are great demands for exhibition companies and professional talents. Right now Zhoushan has 3 universities,they are Zhejiang Ocean University, Zhejiang International Maritime College and Zhejinang Ocean University Donghai Science and Technology College. According to the official college website, none of those colleges have exhibition major. Therefore, those colleges can't cultivate and transport professional talents.

\subsubsection{Professional Facilities are Not Perfect}

As economies of scale, only when exhibitions have reached decent size can they be competitive. Based on domestic exhibition experience, exhibition area should be bigger than 30 thousand square meter, otherwise, exhibition don't have the ability to gain profits. Right now, Zhoushan don't have its 
special convention and exhibition center. Most of time, the exhibition venue are transformed from large-scale hotel or gymnasium. As quantity and scale of exhibition get improved, fire control and height of temporary site doesn't meet the professional requirements, and the demand for the quality of exhibition also get improved. With the development of exhibition industry, hotel and gymnasium in Zhoushan can't adapt to all aspects of requirements. That is why Zhoushan need professional exhibition sites in order to develop exhibition industry.

Exhibition needs booth build-up, exhibition leasing, internet publicity and other related supporting services. At present, Zhoushan lack of relevant supporting industry. Like most regions in China, Zhoushan don't have specific exhibition management organization at present, dearth technical and economic evaluation criteria for exhibition activities. Also, Zhoushan don't have rounded system of exhibition area, customer service, number of international standard booths and other industry statistics. The role of industry association in Zhoushan hasn't work yet, and it also hasn't form into integrated force. The function of social intermediary organization isn't reach the designated position. This shows that it is not only the performance of low marketization in exhibition industry, but also another important factors that restrict the development of exhibition industry in Zhoushan. For a long time, Zhoushan hasn't form exhibition industry association and play a part in other intermediary organizations. Without unified regulations and industry rules, the mechanism of exhibition in self management, self restriction, self development is not sound. Without the power of holding exhibitions, the association can't provide better services to enterprises.

The principal part of exhibition industry market is enterprise, but the number of registered company that work on exhibition industry is very small, and that means no single company have the ability to hold international or foreign exhibition.

\subsection{Opportunity}

\subsubsection{The Support from State}

The article The Analysis of 2018 China Exhibition Industry Development Status and Exhibition Industry Trend mentioned that the exhibition industry has become an important stage to display nation diplomacy. With the increasing level of economic globalization, exhibition industry plays an important role in promoting trade contracts, technical communication, information communication, economic cooperation and increasing employment. In 2015, the State Council issued A Number of Views on Further Promoting the Reform and Development of the Exhibition Industry and deployed the reform and development of exhibition industry at the national level. Meanwhile, the Ministry of Commerce regarded exhibition industry as key component to develop modern service industry. The government also encourage all kinds of firms to hold exhibition based on the market demand. Not only the central government, but also the local government all attach great importance to develop exhibition industry and write the plan into the government performance report.

\subsubsection{Good Development Prospect}

With the acceleration of economic development in Asia-Pacific region and other emerging market countries, international exhibition industry has a trend to shift the center from developed countries to developing countries. According to predictions from international authority, mutual demands form international market and Chinese market will pull the international exhibition industry to the East. China is one of the most politically and security stable countries in the world, with fast and steadily growing economy and increasing communication between domestic and foreign enterprises. Those advantages provide great opportunity for Zhoushan to develop exhibition industry.

\subsubsection{Unique Feature of Zhoushan}

Zhoushan has its unique marine culture that is different from other cities. Also, Zhoushan is abound with abundant aquatic resources. Nowadays there are many large scale companies have set up factories in Zhoushan, maintenance of vessel, aquatic product processing, port logistics and other industries are relatively competitive industries for Zhoushan. Zhoushan should make full use of its special advantage industries to form and develop its own exhibition brands. Zhoushan should also highlight its industrial characteristics and achieve dislocation development when having competition with surrounding cities. 


\subsection{Threat}

As China joined WTO, the development of exhibition industry got improved and the exhibition market was opened. The situation caused an outcome that international exhibition organizations and those companies who hold exhibitions had surged in the domestic market, and it caused more intense competition situation in exhibition industry. Meanwhile, same type of exhibition and the strategy to develop exhibition industry in surrounding cities will certainly have a great impact on the development of exhibition industry in Zhoushan. Hangzhou, Shanghai, Ningbo and other cities that are close to Zhoushan have good exhibition industry development prospects. Shanghai is usually the first choice to hold foreign exhibition. These features show that Zhoushan still have a long way to go in it want to develop exhibition industry.

\section{SugGeStion For DeVELOPING Foreign EXHIBITIONS IN ZHOUSHAN}

Based on SWOT analysis, after considering various factors of the external environment and internal conditions for Zhoushan to develop exhibition industry, we can evaluate the future development systematically and thus provide evidence to choose development direction. According to previous description and discussion. As for Zhoushan to develop exhibition industry, right now opportunities and challenges exist side by side, as do hardships and hopes. Under certain conditions, these opportunities, challenges, hardships and hopes will have reciprocal transformation. Practice shows that a city should concentrate on developing its own advantageous industries instead of pursuing so called comprehensive unilaterally development when the conditions are not available. Therefore, for the development of Zhoushan exhibition industry especially the development of foreign exhibition, there are two suggestions.

\subsection{The Government Should Support Exhibition Development Actively}

- Formulate strategic plans to develop exhibition industry. The government should make investigations and determine certain industries that should be stimulated by exhibitions. Also, the government should study the development direction of the city's exhibition industry and make relevant plans to speed up industrial development. Based on urban development situation, the government can provide directional guidance, release key industrial development issues regularly and to make a guiding report on the needs of exhibition industry.

- Introduce preferential policies to speed up the development of exhibition industry. The government should take the lead in advocating industrial support policies that are conducive to the development of exhibition industry and implement different policies in different aspects such as infrastructure construction, foreign exchange, talent training and so on. These years, many foreign exhibitions are held by non-local companies. In order to maintain healthy development of exhibition industry in Zhoushan, the government should increase the examination of enterprises' qualifications for holding exhibitions to avoid the occurrence of low quality exhibitions.

- Cultivate professional talents and establish human resources database. Exhibition industry has high requirements for comprehensive technology, relevant employees should have not only solid professional knowledge but also extensive relevant knowledge. Right now professional talents in Zhoushan are still in short. The government should take the lead in accelerating personnel training and form a professional team whose team members are familiar with exhibition business and have rich management experience. First, the government can set up exhibition management major in Zhoushan universities and make full use of the advantages of higher vocational education in Zhejiang International Maritime College. By this way the college can cultivate professional talents that master the exhibition industry knowledge and also know actual works. Meanwhile, exhibition industry associations are supposed to organize short term training regularly to train existing talents. Second, make full use of the advantages of Yangtze River delta economic circle, recruit talents who has professional exhibition experience and strong ability to organize and plan exhibition especially foreign exhibition. The government can also establish human resource database and improve the professional quality and level of exhibition staffs comprehensively.

- Improve existing exhibitions. Right now there are many special exhibitions in Zhoushan, and they all have good development prospect. The government should pay enough attention to them, summarize its own shortcomings, refer the experience of domestic mature foreign exhibitions, combine its unique geographical advantages and long marine history to improve existing 
exhibitions and make every efforts too better. The goal is to get a foothold in domestic exhibition market.

\subsection{Take the Advantage of Ocean Features and Plan New Exhibitions}

Zhoushan has always enjoyed the reputation of being "The city of thousand islands". There are many famous islands in Zhoushan, such as Dongji Island, Taohua Island and so on. These islands have distinctive tourist attractions, but most of them became underutilized. The government can make full use of these beautiful islands and plan new foreign exhibitions based on the characteristics of the island. Take Taohua Island as example, it has beautiful scenery. The Taohua Islandis also the place that characters from The Legend of The Condor Heroes and The Return of The Condor Heroes live. The shadow of peach blossom falls to the sword of god, and the tide of the blue sea rises according to the Jade flute. This poem form the fiction referred the Taohua Island. The Taohua Island has its own unique natural landscape advantages, with the organic integration of beautiful scenery and myth, Taohua Island has formed six major scenic spots including Martial arts culture, Buddhist culture and Taoist culture tourist routes. The Taohua Island has the most beautiful blossom scenery during March to April every year, so by making full use of good tourism resources in Taohua Island, the government can plan foreign exhibitions with special island characters, which is called The Peach Flower Festival.

Based on different scenery in Taohua Island, the writer has imagined specific contents of Peach Flower Festival and it has four parts including good place to pray, the peach blossom fair, photography contest and martial arts world.

- Good place to pray. There are many meanings and symbols of peach blossom. The language of peach blossom is the lover in captivity. In Chinese, people usually use tao hua yun to describe someone that he or she has good luck with opposite sex. When the peach blossoms are in full bloom, tourists can come to Taohua Island to pray. Whether it is looking for marriage or pray with lovers, Taohua Island is the ideal place full of love. An ancient prose called The Travel of The Peach Blossom Garden described a perfect Arcadia that stayed away from the turmoil of war. Right now many people use an idiom called The Peach Garden to refer to fairyland on earth. Pray for peach blossom also shows people's hope and yearn for a better life. Meanwhile, there is an idiom that can be translated as have students all over the world. This idiom use peach blossom to analogy students. Therefore, peach blossom is also a symbol of excellent academic achievements. Have so many meaning of peach blossom, the Taohua Island is a good place for all tourists to pray.

- The peach blossom fair. The peach blossom market is an excellent stage to express Chinese culture. With the rise of China's international status, Chinese culture has gained more and more attention. One of the best known is Han Chinese clothing, it is also a name card of Chinese culture. By combining Han Chinese clothing and peach blossom, every tourist who attend the fair will wear Han Chinese clothing and experience different ancient Chinese culture. In the mean time, there are many manual delicate and seafood in Taohua Island. They can be sold in the fair to promote local economic development. The peach blossom can be watched and also can be cooked. Peach blossom petals can be cooked as peach blossom crisp, peach blossom porridge, peach blossom wine and so on. It can be also used in cooking Western food. By inviting domestic and foreign chefs of Chinese food and Western food, tourists can taste different types of delicate and select their favorite food. By this way, visitors can see the peach blossom and taste it.

- Photography contest. There are many unique scenes in Taohua Island where Buddhist culture and Taoist culture are mutually reinforcing, each of the six scenic spots has its own characteristics. Taohua Island has the highest peak in Zhoushan, the Anqi Peak. It also has the largest rock in the southeast coast and the first deep port in Zhoushan. By inviting photography enthusiasts at home and abroad to participate in a three-day photography contest, they can use the camera to record beautiful scenery in Taohua Island. The whole event will be carried out online and offline simultaneously and also hold a five-day photography exhibition. Every visitor can feel the most charming and energetic Taohua Island.

- Martial arts world. Jin yong(Louis Cha, Chinese contemporary martial arts writer)'s novel are famous all over the world and countless people are full of longing to the martial arts world. There 
is a outdoor film studio in Taohua Island where TV series called The Legend of The Condor Heroes and The Return of The Condor Heroes are shot here. The film studio has natural landscape and architecture with the connotation of martial arts culture in Song Dynasty. By learning from Disney's live-action characters, the film studio can use real people to play fictional characters and act stories from fictions and TV series. Every visitor can gain immersive experience in film studio. In Taohua Island, an Arcadia locates in the east China sea, the place that are different form cities other islands, every visitor can be a natural and unrestrained chivalrous man.

\section{REFERENCE}

[1] Daniel Leung, Gang Li, Lawrence Hoc Nang Fong, Rob Law, Ada Lo. (2014) Current state of China tourism research. Current Issues in Tourism 17:8, pages 679-704.

[2] Jin, X., Weber, K., \& Bauer, T. (2013). Dimensions and Perceptional Differences of Exhibition Destination Attractiveness: The Case of China. Journal of Hospitality \& Tourism Research, 37(4), 447-469.

[3] Wang, B. 2004, Contemplation on and Suggestions for the Healthy Rapid Growth of Urban

[4] Exhibition Economy, Market Research, no. 3.

[5] GuoMu, The Yiwu Model of China's Exhibition Economy, Provincial China, Vol. 2, No. 1, September 2010

[6] 黄蔚艳.沿海中小城市会展业发展研究——以舟山市为例[J].中国城市经济,2011(01):36-37+39.

[7] 陈展之.大连会展经济的发展及对舟山的借鉴意义[J].和田师范专科学校学报,2009,28(02):31-33.

[8]＼cjkstart温佳卉,彭勃.舟山桃花岛旅游发展与管理策略研究[J].管理观察,2014(30):169-171.

[9] 贺文洁.中小城市发展会展经济的探讨——温州为例[J].温州大学学报,2005(01):17-20.

[10] 沈铁鸣.从义博会看中小城市发展会展经济之道[J].中国市场,2006(44):12-14.

[11] 王英华. 我国政府在会展业发展中的作用研究[D].华东师范大学,2005.

\section{AUTHORS' BIOGRAPHY}

Cui Yufan, Department of Foreign Languages, Zhejiang Ocean University, Zhejiang, China

He Fangjie, Faculty of Foreign Languages, Zhejiang Ocean University, Zhejiang, China

Citation: Cui Yufan, He Fangjie. The Investigation and Image of Foreign Exhibitions in Zhoushan Pilot Free Trade Zone". International Journal of Humanities Social Sciences and Education (IJHSSE), vol. 6, no.9, 2019, pp. 66-72. doi: http://dx. doi.org/10.20431/2349-0381.0609007.

Copyright: (c) 2019 Authors. This is an open-access article distributed under the terms of the Creative Commons Attribution License, which permits unrestricted use, distribution, and reproduction in any medium, provided the original author and source are credited. 